\title{
MODEL BRAINSTORMING UNTUK MENINGKATKAN HASIL BELAJAR PKN SISWA
}

\author{
Fatma Khaulani, Taufina
}

Surel: fatmakhaulani25@gmail.com

\begin{abstract}
This study aims to improve the quality of PKn grade V learning at SDN 009 Pulau through the application of the Brainstorming model. This research is a class action research consisting of III cycles. The subject of research is the fifth grade students of SDN 009 Pulau Bangkinang District. The results showed an increase in each variable in each cycle. The increase of Civics learning outcomes from an average base score of 62.50 to 69.06 in the first cycle, in the second cycle increased to 75.93 and in the third cycle increased to 80.94. Improved learning outcomes that occur base score to UH I is $10.49 \%$, on UH II scores to $21.49 \%$, and on UH III to $29.50 \%$. The brainstorming model has been proven to be able to improve the quality of learning of PKn grade V SDN 009 Pulau.
\end{abstract}

Keywords: Brainstorming, Civics, Learning Outcomes

\begin{abstract}
ABSTRAK
Penelitian ini bertujuan untuk meningkatkan kualitas beljar PKn kelas V SDN 009 Pulau melalui penerapan model Brainstorming. penelitian ini merupakan penelitian tindakan kelas yang terdiri dari III siklus. subjek penelitian siswa kelas V SDN 009 Pulau Kecamatan Bangkinang. Hasil penelitian menunjukkan peningkatan dalam setiap variabel dalam setiap siklusnya. Peningkatan hasil belajar PKn dari rata-rata skor dasar 62,50 menjadi 69,06 pada siklus I, pada siklus II meningkat menjadi 75,93 dan pada siklus III meningkat menjadi 80,94. Peningkatan hasil belajar yang terjadi skor dasar ke UH I yaitu 10,49\%, pada skor UH II menjadi $21,49 \%$, dan pada UH III menjadi 29,50\%. Model brainstorming terbukti dapat meningkatkan kualitas pembelajaran PKn kelas V SDN 009 Pulau.
\end{abstract}

Kata Kunci: Brainstorming, Hasil Belajar, PKn

\section{PENDAHULUAN}

PKn merupakan salah satu mata pelajaran dalam kurikulum SD/MI. Sebagai mata pelajaran di SD, PKn mempunyai misi sebagai pendidikan nilai Pancasila dan kewarganegaraan untuk warga negara muda usia SD/MI (Sapriya, 2012). Peraturan Menteri Pendidikan Nasional nomor 22 tahun 2006 menjelaskan PKn merupakan mata pelajaran yang memusatkan pada pembentukan warga negara yang memahami dan dapat melaksanakan kewajiban serta haknya untuk menjadi warga negara Indonesia yang cerdas dan berkarakter sesuai dengan amanat dalam pancasila dan UUD 1945. Implementasi pembelajaran PKn pada jenjang sekolah dasar ialah untuk menjadikan siswa SD mempunyai sikap dan karakter yang sesuai dengan pancasila serta UUD dalam berperilaku, sehingga setiap 
siswa mampu menjadi pribadi yang baik. Pembelajaran PKn merupakan hal yang sangat mendasar yang harus dipelajari sebagai usaha penanaman moral pada siswa SD sejak dini. Oleh sebab itu sudah seharusnya proses pembelajaran PKn mendapat perhatian yang lebih. Guru sebaiknya dapat membangun suasana belajar yang baik dan berkualitas agar siswa merasa nyaman dan tertarik untuk mengikuti pembelajaran PKn yang akhirnya dapat memberi dampak pada peningkatan hasil belajar PKn siswa.

Akan tetapi, kenyataan di lapangan belum sesuai dengan tujuan pembelajaran PKn yang diharapkan. Pada saat peneliti melakukan obeservasi lapangan di kelas V SDN 009 Pulau, ditemukannya berbagai maslah yaitu: (1) siswa kesulitan memahami konsep pembelajaran PKn (2) Siswa kurang mampu berinteraksi selama proses pembelajaran, misalnya siswa tidak berani menyampaikan pendapat dan bertanya terhadap suatu materi yang diberikan, (3) Siswa bermain-main saat proses pembelajaran karena merasa bosan. Hal ini disebabkan oleh beberapa faktor, diantaranya: (1) Cara penyajian materi yang disampaikan guru kurang melibatkan aktifitas siswa, (2) Guru menerapkan pendekatan, model atau metode pembelajaran yang kurang menarik bagi siswa.

Permasalahan tersebut juga didukung oleh hasil belajar PKn siswa kelas V belum optimal. Siswa kelas V SD Negeri 009 Pulau berjumlah 16 orang dengan KKM yang ditetapkan pada mata pelajaran PKn yaitu 75. Berdasarkan data hasil belajar siswa PKn yang diperoleh peneliti dari guru kelas V SD Negeri 009 Pulau Kecamatan Bangkinang, diketahui bahwa jumlah siswa yang tuntas adalah 7 Orang dengan persentase ketuntasan $43.75 \%$, jumlah siswa yang tidaktuntas adalah 9 orang persentase $56.25 \%$, serta nilai ratarata kelas yang diperoleh adalah 62 .

Selain itu, Permasalahan diatas didukung oleh hasil penelitian yang telah dilakukan oleh Perwitasari (2014) yang menyatakan bahwa Proses pembelajaran PKn yang dilakukan guru saat ini kurang variatif. Hal ini tampak pada model pembelajaran yang guru digunakan oleh guru yaitu model pembelajaran konvensional, guru menjelaskan pelajaran kepada siswa dengan berceramah, selanjuntnya Wijanarko (2014) menyatakan bahwa Ketika guru meminta komentar atau pendapat siswa mengnai suatru permasalahan, siswa cenderung kurang percaya diri untuk mengeluarkan pendapat serta menjawab pertanyaan dari guru. Hal ini karena siswa dua hal, pertama siswa kurang mengerti terhadap permasalahan yang diberikan oleh guru, dan kedua siswa malu untuk mengeluarkan pendapatnya karena takut diejek oleh temannya yang lain, dan menurut Nasikhah (2016) Siswa kurang fokus dan motivasi selama pembelajaran PKn berlangsung. Hal ini disebabkan oleh pembelajaran satu arah yang diterapkan oleh guru. Siswa 
cenderung menjadi malas untuk mengikuti pembelajaran.

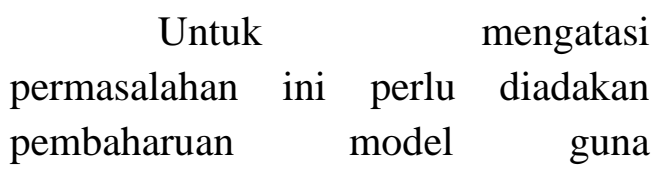

menimbulkan peran aktif siswa dalam pengajaran. Proses pembelajaran siswa diharapkan nantinya bisa aktif dalam ranah afektif dan psikomotorik, sehingga pelajaran PKn menjadi lebih menyenangkan dan dapat meningkatkan hasil belajat. Berdasarkan masalah yang telah dijelaskan, penerapan metode brainstorming merupakan salah satu alternatif perbaikan pembelajaran yang tepat. Metode brainstorming memberikan permasalahan atau topik terlebih dahulu kepada siswa dengan bantuan gambar grafis dan meminta siswa untuk berpartisipasi dalam menyampaikan pendapat terhadap masalah yang diberikan sehingga muncul banyak ide dalam memecahkan masalah tersebut. Kegiatan pembelajaran dengan metode brainstorming ini akan membuat siswa berpikir secara kritis mengenai materi atau permasalahan yang disampaikan oleh guru, selain itu siswa akan menjadi termotivasi dalam mengikuti pembelajaran PKn ini.

Metode Brainstorming
adalah metode yang dipopulerkan
oleh Alex F. Osborn yang dalam
bukunya Applied Imagination, disebut
juga dengan metode sumbang saran.
Metode brainstorming merupakan
suatu bentuk metode diskusi guna
menghimpun ide atau gagasan,
pendapat, dan pengalaman siswa

(Simanjuntak, 2016). Metode brainstorming merupakan sebuah metode pengumpulan gagasan dari sekelompok orang dalam waktu singkat. Metode ini sering digunakan dalam pemecahan/penyelesaian masalah yang kreatif dan dapat digunakan sendiri atau sebagai bagian dari strategi lain. Kegiatan curah pendapat sangat berguna untuk membangkitkan semangat belajar dan suasana menyenangkan kedalam kegiatan kelompok,serta ide kreatif masing-masing peserta didik. (Sani, 2013). Tujuan penggunaan metode ini ialah untuk mengetahui pemikiran siswa dalam menanggapi suatu permasalahan. Metode Brainstorming memiliki perbedaan dengan metode diskusi biasa yang lain. Dalam diskusi pendapat seseorang dapat ditanggapi, dikomentari, bahkan dapat disalahkan. Berbeda dengan metode brainstorming pendapat atau gagasan yang sudah terlontarkan tidak dapat dikomentari, bahkan disalahkan oleh siswa ataupun guru yang mengajarkan. metode brainstorming ini hanya menghasilkan gagasan, sehingga mendorong munculnya banyak gagasan (Simanjuntak, 2016). Menurut Sani (2013) Tahapan yang umum dilakukan dalam menggunakan metode brainstorming adalah sebagai berikut : (1) Memamahi aturan dalam menggunakan metode brainstorming. Pada langkah ini guru harus menyamaikan aturan kepada siswa mengenai pembelajaran menggunakan metode ini serta menempelkan aturan di papan tulis agar siswa senantiasa ingat pada aturantersebut, 
Menuliskan topik atau materi yang akan dibahas pada papan tulis, (3) Guru menunjuk seorang peserta didik untuk menulis ide-ide papan tulis. Peserta didik yang dipilih hendaknya dapat menulis dengan cepat dan terbaca. (4) Guru meminta peserta didik atau kelompok untuk mengemukakan ide yang terkait dengan topik yang dibahas kemudian ide yang diberikan dicatat di papan tulis. (5) Masa inkubasi. Pada langkah ini siswa dan guru berhenti atau istirahat sejenak untuk menetaskan ide. Langkah ini dapat diselingi dengan diskusi untuk mengklarifikasi ide-ide tersebut, bukan untuk mengkritik, (5) Tahap evaluasi ide. Evaluasi dilakukan setelah masa inkubasi.

$$
\text { Selain meningkatkan }
$$

motivasi belajar siswa, metode brainstorming memiliki beberapa keunggulan yaitu: (1) siswa aktif berfikir untuk mengeluarkan pendapat, (2) Mengasah siswa berfikir dengan cepat serta logis, (3) Mendorong siswa untuk siap berpendapat terhadap masalah yang diberikan oleh guru.

Meningkatkan parisipasi siswa dalam pembelajaran. (5) Siswa dapat membantu siswa lain yang kurang aktif dalam pembelajaran. (6) mengupayakann persaingan yang sehat antar siswa, (7) Anak merasa bebas dan gembira, (8) dapat menumbuhkan suasana demokratis dan disiplin.

\section{METODE PENELITIAN}

Penelitian ini dilakukan di SD Negeri 009 Pulau kecamatan Bangkinang Kabupaten Kampar pada semester ganjil 2018/2019. Adapun yang menjadi subjek penelitian adalah siswa kelas V SD Negeri 009 Pulau dengan jumlah siswa 16, 6 orang siswa laki-laki dan 10 orang siswa perempuan dengan kemampuan akademik yang heterogen.

Bentuk penelitian ini merupakan penelitian tindakan kelas (PTK) kolaboratif, yaitu guru dan peneliti bekerja sama. Dalam penelitian ini peneliti merencanakan pelaksanaan penelitian dengan tiga siklus. Satu siklus terdiri dari dua kali pertemuan kemudian dilanjutkan dengan satu kali ulangan siklus. Setiap siklus terdiri dari empat tahapan, yaitu tahap perencanaan, tahap pelaksanaan, tahap pengamatan/evaluasi, dan refleksi.

Teknik observasi dilakukan dengan menggunakan instrumen lembar aktivitas guru dan siswa menggunakan langkah dari model brainstorming. Teknik ini bertujuan untuk melihat ketercapaian siswa pada materi yang diajarkan yang dilakukan pada akhir siklus.

Pengumpulan data-data yang diperoleh salama melakukan penelitian. Analisis Data Aktifitas Guru dan Siswa.

\section{HASIL PENELITIAN DAN PEMBAHASAN \\ Penelitian dilaksanakan dalam tga siklus. Siklus I terdiri dari tga kali pertemuan, dengan pertemuan}


pertama menyajikan materi "Arti penting keutuhan NKRI" dan pertemuan kedua menyajikan materi "Ancaman terhadap keutuhan NKRI". Kemudian pada pertemuan ke tiga dilakukan ulangan harian pertama. Adapun siklus II terdiri dari 3 kali pertemuan, dengan pertemuan pertama menyajikan materi "Dampak dari ancaman terhadap keutuhan NKRI". Dan pertemuan ke dua menyajikan materi "Gerakan separatisme dalam NKRI". Kemudian pada pertemuan ke tiga dilakukan ulangan harian ke dua. Siklus III terdiri dari 3 kali pertemuan, dengan pertemuan pertama menyajikan materi "Bunyi dan lambang pancasila" dan pertemuan kedua menyajikan materi "Sikap yang mencerminkan pancasila dalam menjaga keutuhan NKRI". Pertemuan ketiga dilakukan ulangan harian ketiga.

Peneliti juga telah mempersiapkan semua instrumen yang dibutuhkan dalam kegiatan penelitian, yaitu perangkat pembelajaran dan instrumen pengumpulan data yang diperlukan dalam menerapkan model pembelajaran Brainstorming. Pelaksanaan tindakan dilakukan berdasarkan perencanaan yang telah disusun sesuai dengan penerapan model pembelajaran brainstorming yang dilaksanakan dalam 3 siklus.

Tahap pengamatan dilakukan oleh seorang pengamat, yaitu guru kelas. Pengamatan dilakukan pada waktu tindakan dengan menggunakan lembar pengamatan terhadap metode brainstorming yang diterapkan. Lembar pengamatan aktifitas berupa lembar aktifitas siswa.

Tahap refleksi merupakan tahap intropeksi atau tahap dimana peneliti harus merenungkan kembali apa yang telah dilakukan. Ketuntasan klasikal siswa pada setiap siklus dengan menggunakan model brainstorming.

Berdasarkan hasil penelitian sebelum diterapkannya model brainstorming, ketuntasan klasikal hasil belajar PKn siswa 43,74\%. Kemudian setelah diterapkan model brainstorming pad siklus I ketuntasan hasil belajar PKn siswa meningkat dengan ketuntasan klasikal 56,25\%, pada siklus II ketuntasan klasikalnya meningkat menjadi $68,75 \%$ dan pada siklus III ketuntasan klasikal siswa menjadi lebih baik lagi menjadi $87,50 \%$. Ketuntasan klasikal terjadi apabila $85 \%$ atau lebih dari total keseluruhan siswa yang sudah mencapai KKM setelah diterapkannya metode pembelajaran Brainstorming. Hal ini menunjukkan bahwa model brainstorming yang diterapkan oleh guru dapat meningkatkan hasil belajar dan ketuntasan klasikal siswa.

Berdasarkan hasil penelitian selanjutnya, terjadi Peningkatan aktivitas siswa dalam pelajaran PKn dimana pada pertemuan I jumlah skor yang diperoleh adalah 15 (62,50\%). Pada pertemuan ke II skor meningkat menjadi 16 (66,67\%). Selanjutnya pada pertemuan III skor menjadi 18 (75\%). Kemudian pada pertemuan IV skor menjadi $19 \quad(79,16 \%)$. 
Selanjutnya pada pertemuan ke V menjadi 20 (83,33\%). Kemudian pada pertemuan VI menjadi $21(87,5 \%)$ termasuk.

Aktivitas siswa mengalami peningkatan pada setiap pertemuan karena dengan model brainstorming siswa bersemangat dan antusias dalam pembelajaran, sehingga setiap aktivitas yang dilakukan sesuai dengan langkah-langkah model yang digunakn

\section{Pembahasan}

bahwa $\begin{array}{rr}\text { Penelitian ini menunjukkan } \\ \text { model }\end{array}$ brainstorming dapat meningkatkan hasil belajar dan aktivitas siswa siswa kelas V SD Negeri 009 Pulau Kecamatan Bangkinang Kabupaten Kampar. Berdasarkan analisis hasil belajar peserta dari skor dasar hingga siklus III diperoleh data pskor dasar 62,50 meningkat menjadi 69,06 pada siklus I, sedangkan pada siklus II meningkat menjadi 75,93, dan siklus III menjadi 80,94. Peningkatan hasil belajar dari skor dasar ke siklus I meningkat sebanyak 10,49 \%, sedangkan pada siklus II terjadi peningkatan sebanyak $21,49 \%$ dan pada siklus III meningkat menjadi $29,50 \%$.

Berdasarkan uraian hasil penelitian di atas, menunjukkan bahwa model pembelajaran brainstorming memiliki pengaruh positif terhadap proses belajar dan hasil belajar siswa. Jadi, dapat disimpulkan bahwa hipotesis tindakan sesuai dengan hasil penelitian, karena model pembelajaran brainstorming dapat meningkatkan hasil belajar PKn siswa kelas V SD Negeri 009 Pulau Kecamatan Bangkinang Kabupaten Kampar.

\section{SIMPULAN}

Hasil belajar Pkn siswa meningkat. Nilai rata-rata skor dasar sebelum diadakan tes yaitu 62,50. Setelah diadakan UH I, diperoleh nilai rata-rata siswa 69,06. Pada UH II meningkat dengan nilai rata-rata siswa menjadi 75,93 dan pada siklus UH III nilai rata-rata meningkat menjadi 80,94. Peningkatan hasil belajar yang diperolehsiswa dari skor dasar ke UH I yaitu sebesar 10,49\% sedangkan peningkatan hasil belajar siswa dari skor dasar ke UH II adalah sebesar 21,49\% dan peningkatan hasil belajar siswa dari skor dasar ke UH III yang diperoleh siswa adalah sebesar 29,50\%. Aktivitas siswa pada siklus meningkat dari siklus I pertemuan pertama hingga siklus III pertemuan kedua.

\section{DAFTAR RUJUKAN}

Aqib, Z. 2011. Penelitian Tindakan Kelas untuk Guru SMP, SMA, $S M K$. Bandung: Yrama Wida.

Aqib, Z. 2016. PeneliitianTindakan Kelas. Bandung: Yrama Widya. Arikunto, S., dkk. 2015. Penelitian Tindakan Kelas. Jakarta: Bumi Aksara.

Nasikhah, A. 2016. Pengembangan Game Education Pembelajaran Pkn Materi Menghargai Keputsan Bersama Kelas V SD. Jurnal Kreatif. 1(4) 
Perwitasari, A. 2014. Peningkatan

Kualitas Pembelajaran Pkn

Melalui Model Time Token

Arends Dengan Media Audio

Visual. Joyful Learning Journal. 3(1).

Purwanto, N. 2009. Prinsip-Prinsip dan Teknik Evaluasi

Pengajaran. Yogyakarta: Remaja Rosdakarya.

Sani, R. A. 2013. Inovasi Pembelajaran. Jakarta: PT Bumi Aksara.

Sapriya. 2009. Pendidikan IPS. Bandung: PT Remaja Rosda Karya.

Simanjuntak, D. 2016. Pengaruh Metode Pembelajaran Brainstorming Dengan Menggunakan Media Visual Terhadap Hasil Belajar Siswa Pada Mata Pelajaran Sejarah Di SMA Negeri 1 Sukoharjo Kelas $X$ Tahun Ajaran 2015/2016. Bandar Lampung: Fakultas Keguruan Dan Ilmu Pendidikan Universitas Lampung.

Wijanarko, P. 2014. Numbered Head Together Berbantuan Media Visual Untuk Meningkatkan Kualitas Pembelajaran Pkn. Joyful Learning Journal. 3(1). 